\title{
Discussion of Mrs. E. M. Harrison's Paper
}

\section{THE EDITOR}

Ten years ago Mrs. Harrison, using a technique which she has termed Directional Training, experienced success when attempting to teach braininjured children to learn to write. It is interesting to examine this technique in the light of a recent postulate of the eminent Russian psychologist and neuro-psychiatrist, Professor Luria.

Luria has long been concerned with the application of experimental method to the problems of behaviour, and ranks as an experimental psychologist of high repute. His interest in language is demonstrated by the importance which

fournal of the South African Logopedic Society, Vol. 12, No. 1: September 1965 
he attaches to the study of child development. In his opinion the study of language and its development is the key to our understanding of vital problems in human intellectual growth.

In his book The Role of Speech in the Regulation of Normal and Abnormal Behaviour, Luria has shown that the perception of a child can be controlled and modified through speech. This idea is contrary to the conventional way of thinking about perception as being merely a reaction which takes place through a sense organ.

In order to substantiate this point of view, Luria quotes certain experiments. Experiment I. Children aged 12-30 months were given small red and green boxes, the green empty and the red containing sweets. It proved very difficult for the children to select the correct boxes (i.e. those containing sweets) in a choice situation. However, when speech entered the experiment by the experimenter naming the colours of the two boxes and then asking the children to select the correct one, the significant cue stood out boldly and the children were able to make a correct selection.

This experiment clearly demonstrates how speech can substantially modify a child's perception and by so doing permit "the working out of a system of stable differentiated associations."

Luria has further demonstrated this regulatory role which speech exerts on behaviour in his experimental work with brain-injured patients. Of particular interest are his experiments with patients suffering from Parkinsonism, where the motor system is directly affected but where, as Luria states, the "verbal system" is considerably intact.

Experiment 2. A subject suffering from Parkinsonism was asked to answer the following questions with his fingers:

i. How many wheels are there on a car?

ii. How many brothers have you?

iii. How many points on the red star?

Whereas formerly the patient had lost movement in his hand, when answering the foregoing questions movement was regained. According to Luria what had occurred was that although the hands had lost their primary function, when used for the purpose of answering questions, they entered a complex verbal functional system where the defective movement was compensated for. In fact, by adding a new system of intact verbal afferentation to the defective movement, it is possible to switch the process to a new level and attain, as Luria postulated, "a form of self-regulation" of a process which was previously inaccessible.

Returning to Mrs. Harrison's work, it seems apparent that her technique of directional training, where the children she taught verbalized while carrying out movement and interpreted verbally movements made by other children, can be closely linked to Luria's ideas. She, too, was in fact linking a relatively intact verbal system to a system which was defective, and by so doing enabled her pupils to compensate for their disabilities.

It is indeed commendable that ten years ago Mrs. Harrison should have devised this technique, the theory behind which has only become accessible to us in a work published for the first time in 1961 . 


\section{Opsomming}

Die tegnieke wat Mev. E. M. Harrison gebruik om sekere breinbeseerde kinders wat nie fisies gestrem is nie, te leer skryf, is in verband gebring met die werk en bevindings van die beroemde Russiese sielkundige en neuropsigiater, Prof. A. R. Luria. Luria stel dit dat spraak'n regulerende invloed uitoefen op 'n kind se gedrag en 'n spesifieke invloed het op die ontwikkeling van sy verstandsprosesse.

Deur die gebruik van die Rigtingwysende Opleiding het Mev. Harrison bewys dat breinbeseerde kinders, sonder fisiese stremming, maar wat nie deur die gebruiklike metodes kon leer skryf nie, tog die vaardigheid kon aanleer sodra as spraak met die spesifieke aksie van skryf verbind word.

Op dieselfde wyse het Luria bewys dat sekere gevalle van Parkinsonisme in staat gestel word om hulle hande suksesvol te gebruik wanneer die spesifieke beweging verbind word met die verbale meganismes.

Blykbaar word, deur die byvoeging van 'n nuwe stelsel van onbelemmerde verbale afferentasie by die afwykende beweging, 'n verskuiwing van die proses na $n$ nuwe en suksesvolle peil bewerkstellig. Hierdie peil kan nie deur die konvensionele opleidingsmetodes bereik word nie.

\section{REFERENCES}

Luria, A. R. (196I): The Role of Speech in the Regulation of Normal and Abnormal Behaviour. London: Pergamon Press.

Luria, A. R. and Yudowich, F. Ia. (I959): Speech and the Development of Mental Processes in the Child. London: Staples Press. 